\title{
Best diagnostic approach for the genetic evaluation of fetuses after intrauterine death in first, second or third trimester: QF-PCR, karyotyping and/or genome wide SNP array analysis
}

\author{
Angelique JA Kooper* , Brigitte HW Faas, Ilse Feenstra, Nicole de Leeuw and Dominique FCM Smeets
}

\begin{abstract}
Background: The aim of this study was to evaluate the best diagnostic approach for the genetic analysis of samples from first, second and third trimester intrauterine fetal deaths (IUFDs). We examined a total of 417 IUFD samples from fetuses with and without congenital anomalies. On 414 samples, karyotyping $(\mathrm{N}=46)$ and/or rapid aneuploidy testing by QF-PCR $(N=371)$ was performed). One hundred sixty eight samples with a normal test result were subsequently tested by genome wide Single Nucleotide Polymorphism (SNP) array analysis. Three samples were only analyzed by array.

Results: In 50 (12.0\%) samples an aneuploidy was detected by QF-PCR and/or karyotyping, representing 47.1\% of first, $13.2 \%$ of second and $3.4 \%$ of third trimester pregnancies. Karyotyping and QF-PCR failed in 4 (8.7\%) and 7 (1.9\%) samples, respectively, concerning mostly contaminated amniotic fluid samples from third trimester pregnancies. Clinically relevant aberrations were identified in $4.2 \%$ (all fetuses with malformations) of the 168 samples tested by SNP array. Inherited copy number variants (CNVs) were detected in 5.4\% and $8.9 \%$ showed CNVs of unknown clinical relevance as parental inheritance could not be studied yet. In a sample from a fetus suspect for Meckel-Grüber syndrome, the genotype information from the SNP array revealed various stretches of homozygosity, including one stretch encompassing the CEP290 gene. Subsequent CEP290 mutation analysis revealed a homozygous, pathogenic mutation in this gene.
\end{abstract}

Conclusions: Based on our experience we recommend QF-PCR as the first-line test in IUFD samples of first and second trimester pregnancies to exclude aneuploidy before performing array analysis. The chance to detect aneuploidy in third trimester pregnancies is relatively low and therefore array analysis can be performed as a first-tier test. A tissue sample, instead of amniotic fluid, is preferred because of a higher success rate in testing.

We emphasize the need for analysis of parental samples whenever a rare, unique CNV is detected to allow for better interpretation of such findings and to improve future pregnancy management. Furthermore, we illustrate the strength of SNP arrays for genotype analysis, even though we realize it is crucial to have detailed phenotypic information to make optimal use of the genotype data in finding candidate recessive genes that may be related to the fetal phenotype.

Keywords: Intrauterine fetal death, IUFD, DNA, QF-PCR, Karyotyping, SNP array

* Correspondence: Angelique.Kooper@radboudumc.nl

Department of Human Genetics, Radboud university medical center,

Nijmegen, The Netherlands 


\section{Background}

There are numerous causes of fetal death, including genetic conditions, infections, placental abnormalities, and fetal-maternal hemorrhage. Valuable tests for the evaluation of fetal death are perinatal autopsy, placental examination, cytogenetic analysis, and testing for fetal maternal hemorrhage [1,2]. The first trimester of pregnancy, usually defined as the period from fertilization until the 13th week of gestation, is the most sensitive time of development for the conceptus and a relatively high incidence of first trimester spontaneous abortion is reported. Although maternal exposure to certain teratogens and possible immune rejection of the conceptus do occur, the most common cause of first trimester spontaneous abortion is a chromosomal abnormality [3-8]. Chromosomal abnormalities found in second trimester losses are similar to those found in live births; the most common are trisomies 13, 18, and 21, monosomy $X$, and sex chromosome polysomies [9]. Second (13-27 weeks) and third trimester (28-42 weeks) fetal death can also be attributed to many other single or multiple causes. Beside fetal anomalies placentation and cord morbidities, or maternal co-morbidities may play a major role. However, a cause-and-effect relationship is often difficult to establish. The most common cause of intrauterine fetal death (IUFD) in the third trimester appears to be umbilical cord accidents [4-6].

Karyotyping of IUFD samples requires viable cells. As karyotyping fails in up to $40 \%$ of the cases due to culturing failure, molecular testing of IUFD samples by Multiplex Ligation-dependent Probe Amplification (MLPA) or Quantitative Fluorescent Polymerase Chain Reaction (QFPCR), for the detection of the most common aneuploidies, has proven to be very helpful as cell culture is not required $[10,11]$. The microarray technology already proved its value in post- and prenatal diagnostics as it enables the detection of submicroscopic aberrations (gains and losses) with a very high resolution [12-20]. Moreover, it overcomes many of the limitations of routine karyotyping [7,10,21,22]. Since January 2010 our diagnostic centre routinely performs array analysis in IUFD samples associated with congenital anomalies after exclusion of the most common aneuploidies. Since February 2012 array analysis is also been performed for IUFD samples without congenital anomalies (and without a common aneuploidy).

In this retrospective study, we evaluated the results of various genetic tests in samples of IUFD from first, second and third trimester pregnancies. Next to the results of traditional karyotyping and QF-PCR, we illustrate the strength of Single Nucleotide Polymorphisms (SNP) array analysis based on genotyping data.

\section{Methods}

From January 2010 until August 2012, 417 samples of fetal death in utero were investigated. Genetic studies were performed on all IUFD samples either by analysis of material obtained after invasive prenatal testing before induction of labor (amniotic fluid or chorionic villi, $\mathrm{N}=57$ ) or by analysis of postpartum obtained tissue of the fetus (fetal skin, placental and/or umbilical cord material, $N=360$ ). All samples were analyzed at the Radboud university medical center in Nijmegen for genetic examination. Gestational age of the pregnancy and clinical information about the fetus were collected from the genetic test request form.

\section{DNA for QF-PCR}

Tissue samples were minced and treated with collagenase to obtain a cell suspension. Subsequently, DNA was isolated following standard procedures by robot (Chemagic Magnetic Separation Module 1 from Chemagen, Baesweiler, Germany).

From chorionic villi, the cytotrophoblast and mesenchymal core fraction were enzymatically dissociated with trypsin/EDTA followed by collagenase treatment. Genomic DNA for QF-PCR was extracted from both villi fractions. DNA was extracted from $1 \mathrm{ml}$ uncultured amniotic fluid using a Chelex based procedure (Instagene Matrix, Bio-Rad Laboratories, Hercules, CA, USA).

\section{DNA for array}

DNA isolated from tissue samples for QF-PCR was also used for array.

From chorionic villi, only DNA isolation from the mesenchymal core fraction was performed for array analysis using the QIAamp DNA Mini Kit (Qiagen Benelux $\mathrm{BV}$, Venlo, the Netherlands), following the instructions of the manufacturer.

From uncultured amniotic fluid, DNA from $6 \mathrm{ml}$ was isolated, using the QIAamp MinElute Virus spin kit (Qiagen Benelux BV, Venlo, the Netherlands) and eluted in $50 \mu \mathrm{l}$ of elution buffer.

\section{QF-PCR}

Two different QF-PCR kits were used: tissue samples were tested for aneuploidies of the chromosomes 13, 15, 16, 18, 21, 22, X, or Y (kit Devyser Extend, Cytogen, Sinn, Germany), while chorionic villi and amniotic fluid samples were tested for aneuploidies of the chromosomes 13, 18, 21, X and Y (Aneufast, Genomed Ltd, UK).

Whenever an aneuploidy was detected, cytogenetic evaluation of parental blood followed to study whether the fetal abnormality could be due to a parental rearrangement.

\section{Karyotyping}

In 46 of the 57 chorionic villi or amniotic fluid samples, karyotyping was the first-line test due to the fact that at that time the QF-PCR was not yet implemented as a 
first-line test for prenatal IUFD samples. Karyotyping was performed following standard procedures.

In three samples, culturing of the fetal material and/or QF-PCR could not be carried out and, therefore, only array analysis was performed.

\section{Array}

After a normal QF-PCR or karyotype result, genome wide array analysis was performed on DNA from 168 IUFD samples from fetuses with or without malformations (before February 2012 array was only performed on IUFD samples with malformations or on request, from February 2012 routinely on all IUFD samples).

Seventy one samples were tested using the Affymetrix GeneChip 250 k (NspI) SNP array platform (Affymetrix, Inc, Santa Clara, California, USA), which contains 25mer oligonucleotides representing a total of 262,264 SNPs (Method, see [13]). Data were analyzed with the CNAG software package [14]. The other 97 array analyses were carried out following the manufacturer's protocols on the high resolution CytoScan HD array platform which contains more than 2.6 million markers, including 750,000 genotype-able SNPs and 1.9 million non-polymorphic probes. Data were analyzed with the Affymetrix Chromosome Analysis Suite (ChAS) software (Affymetrix, Inc, Santa Clara, California, USA). The two major quality control metrics for Affymetrix array are the Median Absolute Pairwise Difference (MAPD) score which applies to copy number probes and the SNP-QC which applies to SNP probes. In our diagnostic setting, the values for these parameters need to be $\leq 0.25$ for MAPD and $\geq 0.15$ for SNP-QC.

We set the cut-offs for our detection criteria for copy number variants (CNVs) at $20 \mathrm{~kb}$ for gains, $10 \mathrm{~kb}$ for losses and 1,250 kb for Regions Of Homozygosity $(\mathrm{ROH})$. Our reporting criteria for $\mathrm{CNVs}$ depend on the gene content and on the size. Follow-up testing on parental samples is, based on the size of the $\mathrm{CNV}$, performed by array, Fluorescence In Situ Hybridization (FISH) and/or karyotyping. An overview of our recommendations concerning the detection and reporting criteria for diagnostic array results and follow-up testing is shown in Table 1. The breakpoint positions of each aberrant region were converted to UCSC hg19 (UCSC Genome Browser, release February 2009).

CNVs were classified as (a) benign, (b) likely/probably benign, (c) of uncertain clinical relevance, (d) of unknown clinical significance because of unknown inheritance, (e) likely/possibly clinically relevant or (f) clinically relevant.

A variant was categorized as benign if its full length had been reported in at least three apparently unaffected individuals as listed in the Database of Genomic Variants [23] or our in-house databases containing array data from healthy control individuals (i.e., volunteers, blood donors, etc.). A CNV was likely/probably benign when an identical CNV was inherited from an healthy parent and likely/probably clinically relevant whenever the CNV had been described in a single case report but with well-defined phenotype, specific and relevant to the IUFD. Clinically relevant variants had evidence of pathogenicity according to the published literature, often containing a gene known to be relevant in fetal development or fetal death as listed in the Online Mendelian Inheritance in Man (OMIM) database. Variants that did not meet the criteria for classification as clinically relevant or benign were classified as CNVs of uncertain clinical significance, or as CNVs of unknown clinical significance because of unknown inheritance because parental inheritance could not be determined yet.

In addition to copy number analysis, SNP array data analysis also enabled genotyping of the array data and the detection of homozygous stretches. Regions Of Homozygosity $(\mathrm{ROH})$ with a size $>10 \mathrm{Mb}$ were evaluated for autosomal recessive conditions in fetuses with a clinical phenotype using a clinical evaluation tool for SNP arrays (Genomic Oligoarray and SNP array evaluation tool v2.0) [24]. This tool systematically searches through relevant databases including the OMIM database, the University of California at Santa Cruz Genome Browser (UCSC), and the National Center for Biotechnology Information (NCBI) database, to rapidly identify disease genes mapping to the $\mathrm{ROH}$ to enumerate associated autosomal recessive clinical disorders and their clinical features.

\section{Results}

An overview of all samples and diagnostic test results is shown in Figure 1.

\section{QF-PCR/Karyotyping}

In $50(12.0 \%)$ samples an aneuploidy was detected. This was $47.1 \%(8 / 17)$ in first trimester samples, $13.2 \%(35 / 265)$ in second trimester samples, $3.4 \%(4 / 116)$ in third trimester samples, and $15.8 \%(3 / 19)$ in the samples of unknown gestational age. The aneuploidies included trisomy $13(\mathrm{~N}=9)$, trisomy $18(\mathrm{~N}=4)$, trisomy $21(\mathrm{~N}=18)$, monosomy $\mathrm{X}(\mathrm{N}=12)$, triploidy $(\mathrm{N}=6)$ and one mosaic trisomy 7 (Figure 2).

Karyotyping $(\mathrm{N}=46)$ failed in four (8.7\%) amniotic fluid samples. These four samples were from third trimester pregnancies and were contaminated with old blood.

QF-PCR $(\mathrm{N}=368)$ failed in seven samples $(1.9 \%)$. Two of these were amniotic fluid samples which were contaminated with old blood. In both cases, diagnostic testing could successfully be performed by array. In the first case, also umbilical cord was received and examined, 
Table 1 Recommendations concerning the detection and reporting criteria for diagnostic array results and follow-up testing

\begin{tabular}{|c|c|c|c|c|}
\hline Detection criteria & Gain & Loss & ROH & \\
\hline Minimum marker count & 10 & 10 & 500 (SNP probes) & \\
\hline Minimum size (kb) & 20 & 10 & 1250 & \\
\hline \multirow[t]{8}{*}{ Reporting criteria } & Gene content of CNV & Size of CNV (kb) & & \\
\hline & Known disease gene, matching the phenotype & $<20$ & & \\
\hline & Known disease gene $(s)^{*}$ & $>20$ & & \\
\hline & No disease gene(s) & $>100$ & & \\
\hline & No genes & $>500$ & & \\
\hline & ROH & Size of ROH (Mb) & & \\
\hline & & $>10$ & $\begin{array}{l}\text { Genomic Oligoarray and SNP array evaluation } \\
\text { tool v2.0 }{ }^{[24]} \rightarrow \text { recessive disease causing genes } \\
\rightarrow \text { mutation detection }\end{array}$ & $\begin{array}{l}\text { Positive } \rightarrow \text { Parental mutation carrier } \\
\text { analysis }\end{array}$ \\
\hline & & $<10$ & $\begin{array}{l}\text { In case of a specific clinical suspicion for a known } \\
\text { syndrome } \rightarrow \text { Genomic Oligoarray and SNP array evaluation } \\
\text { tool v2. }{ }^{[24]} \rightarrow \text { recessive disease causing genes } \rightarrow \text { mutation } \\
\text { detection }\end{array}$ & $\begin{array}{l}\text { Positive } \rightarrow \text { Parental mutation carrier } \\
\text { analysis }\end{array}$ \\
\hline \multirow[t]{4}{*}{ Parental testing } & Type of CNV & Follow-up test & & \\
\hline & Uncertain & Array analysis & & \\
\hline & Clinically relevant: & & & \\
\hline & - cytogenetically visible (> 5-10 Mb) & Karyotyping & & \\
\hline
\end{tabular}

- submicroscopic aberration $(<1-10 \mathrm{Mb})$

FISH

*Depending on the referral reason for array, in this case intrauterine fetal death, a certain CNV will sometimes not be reported, even though our general reporting criteria are met. For example, if it concerns a $50 \mathrm{~kb}$ loss in an OMIM disease gene that is not involved in embryonic and fetal development. Alternatively, a certain CNV is reported, but in the explanatory text of the array report it is mentioned that this CNV is not very likely causative for the IUFD. 


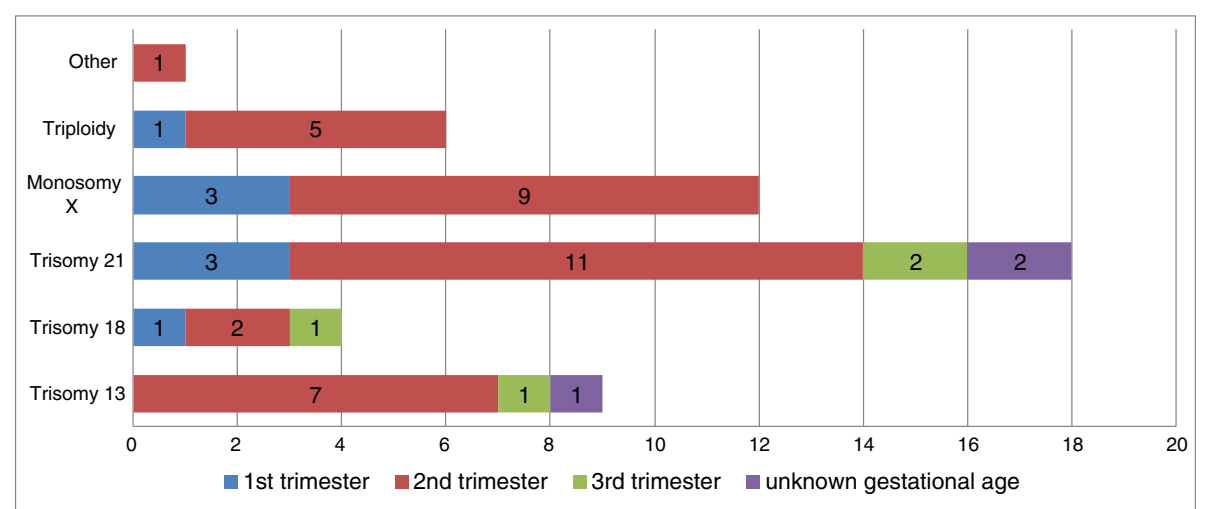

Figure 1 Distribution, number and type of aneuploidy detected in the cohort of 417 IUFD samples.

and in the second case amniotic fluid cells could be cultured and used for DNA isolation and array. The QFPCR test of two skin biopsies failed because DNA was of poor quality due to degradation. We did not obtain interpretable results by QF-PCR in three placenta samples because of maternal cell contamination. In one sample with maternal contamination array was performed, the sample was from a male fetus with an paternally inherited unbalanced translocation $\mathrm{t}(17 ; 18)$.

\section{Array}

In 168 samples examined by array one test failure (Cytoscan HD) occurred because the DNA was of poor quality due to degradation. Six samples did not meet our quality criteria and were therefore analyzed with an adjusted resolution of $1 \mathrm{Mb}$.

\section{Copy number variants (CNVs)}

A normal array profile was detected in 136 out of 168 (81.0\%) samples. In seven (4.2\%) samples, one or more (likely) clinically relevant CNVs were detected (Table 1 ), with sizes ranging from 1.1 to $48.0 \mathrm{Mb}$. To define whether the CNVs had occurred de novo, were inherited, or caused by the presence of a parental balanced translocation, additional parental testing was performed in six of the seven samples. Only in case id 60 blood was requested but not yet received. Parental karyotyping was performed in five samples and normal karyotypes were obtained in nine parents. In case id 206, the father appeared to be carrier of a balanced reciprocal translocation $46, \mathrm{XY}, \mathrm{t}(17 ; 18)$ (q23;q21.1), as is also indicated in the fetal karyotype in Table 2. Parental testing was performed by FISH in case id 296 and revealed a normal 22q11.2 FISH pattern in both parents.

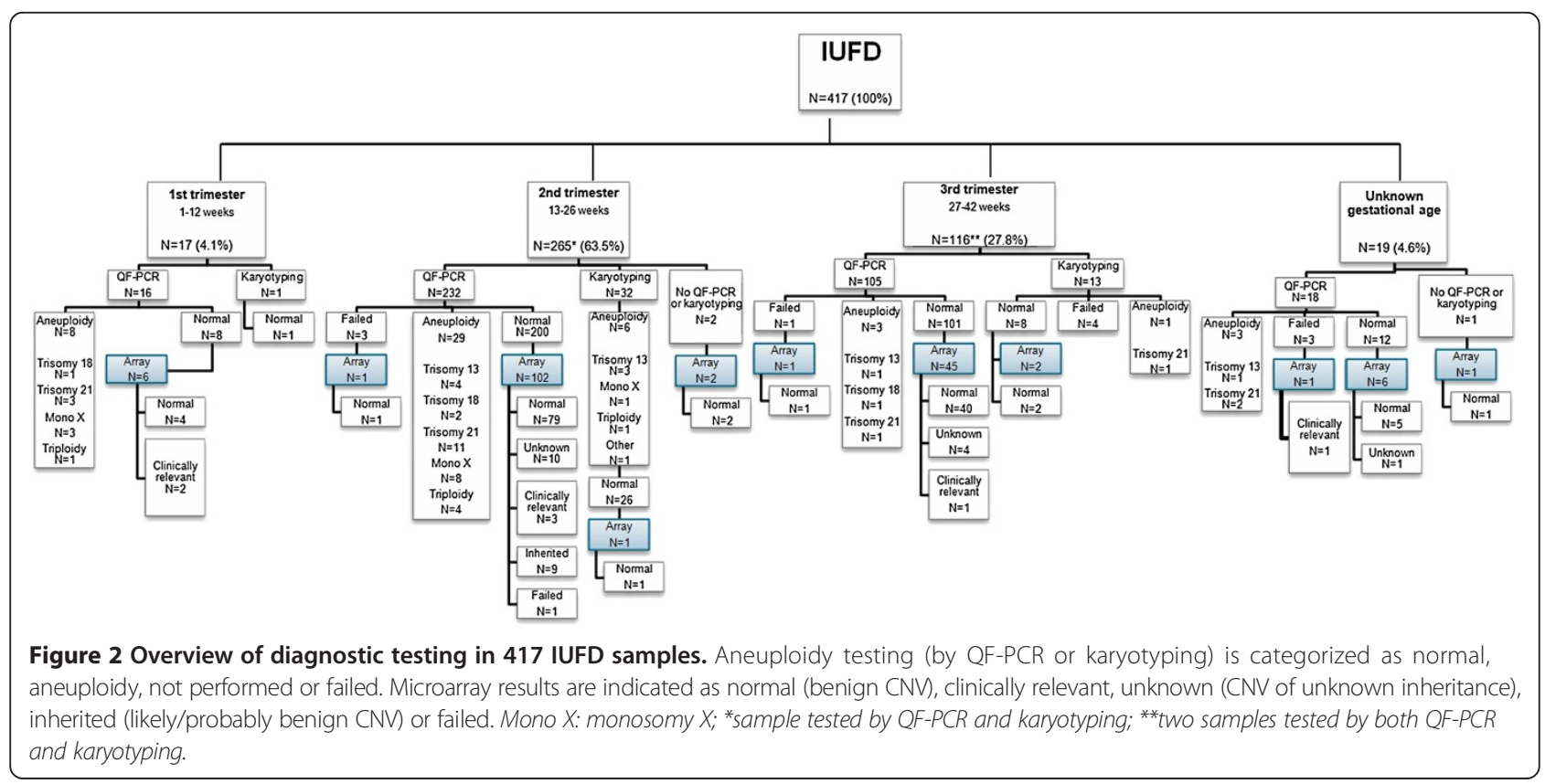


Table 2 CNVs that are clinically relevant $(\mathrm{N}=7)$

\begin{tabular}{|c|c|c|c|c|c|c|c|c|}
\hline Case id & $\begin{array}{l}\text { Pregnancy } \\
\text { trimester }\end{array}$ & Clinical features & Array platform & $\begin{array}{l}\text { Size } \\
(\mathrm{Mb})\end{array}$ & Chromosomal region & $\begin{array}{l}\text { Start-end } \mathrm{Mb} \\
\text { position }(\mathrm{Hg} 19)\end{array}$ & CNV & $\begin{array}{l}\text { Disease-causing OMIM genes } \\
\text { involved (UCSC feb 2009) }\end{array}$ \\
\hline 60 & first & Hydrops fetalis & CytoScan ${ }^{\oplus} \mathrm{HD}$ & 8.4 & $3 p 24.2 p 24.3$ & $17269256-25630783$ & loss & THRB \\
\hline \multirow[t]{3}{*}{206} & unknown & MCA & $250 \mathrm{k}$ & 8.4 & $17 q 23.1 q 25.3$ & $70175362-78598059$ & gain & $\sim 19$ genes* \\
\hline & & & & 26.8 & $18 q 21.2 q 23$ & $49229300-76115293$ & loss & $\sim 13$ genes* \\
\hline & & & & & & & $\mathrm{t}(17 ; 18)$ pat & \\
\hline \multirow[t]{2}{*}{212} & third & $\begin{array}{l}\text { Unilateral talipes calcaneovalgus, } \\
\text { unilateral ear tag }\end{array}$ & $250 \mathrm{k}$ & 11.8 & $5 p 15.2 p 15.33$ & 81949-11834131 & dn loss & $\begin{array}{l}\text { SDHA, SCL6A19, TERT, SLC6A3, NDUFS6, } \\
\text { NSUN2, MTRR, CCT5 }\end{array}$ \\
\hline & & & & 4.3 & $5 p 15.1 p 15.2$ & $11857228-16124168$ & dn gain & DNAH5, ANKH \\
\hline \multirow[t]{3}{*}{274} & second & Edema (hands and feet) & CytoScan ${ }^{\circledast} \mathrm{HD}$ & 48.0 & $1 \mathrm{q} 32.1 \mathrm{q} 44$ & $201214014-249224685$ & dn gain & $\sim 50$ genes* \\
\hline & & & & 1.1 & $9 p 24.3$ & 203862-1293115 & dn loss & DOCK8, KANK1 \\
\hline & & & & 37.5 & $9 p 13.1 p 24.3$ & $1293354-38787480$ & dn gain & $\sim 30$ genes* \\
\hline 296 & second & $\begin{array}{l}\text { Hypertelorism, micrognathia, } \\
\text { microencephaly, flat face }\end{array}$ & CytoScan ${ }^{\circledast} \mathrm{HD}$ & 3.2 & $22 q 11.21$ & $18644791-21800798$ & dn loss & $\begin{array}{l}\text { PRODH, GP1BB, TBX1, COMT, RTN4R, SCARF2, } \\
\text { HCF2, SNAP29 }\end{array}$ \\
\hline \multirow[t]{2}{*}{309} & first & Exencephaly & CytoScan ${ }^{\circledast} \mathrm{HD}$ & 18.4 & 18p11.32p11.1 & 136227-18521286 & dn loss & $\begin{array}{l}\text { SMCHD1, LPIN2, TGIF, NDUFV2, APCDD1, GNAL, } \\
\text { AFG3L2, MC2R }\end{array}$ \\
\hline & & & & 19.3 & $18 q 21.32 q 23$ & 58738938-78014124 & dn gain & PIGN, TNFRSF11A, BLC2, RTNN, CYB5A, TSHZ1, CTDP1 \\
\hline 317 & first & Hydrops fetalis & CytoScan ${ }^{\circledast} \mathrm{HD}$ & 23.0 & $9 q 22.33 q 33.2$ & $101052575-124018186$ & dn loss & $\sim 20$ genes* $^{*}$ \\
\hline
\end{tabular}

*Number of disease-causing OMIM genes $>10 \rightarrow$ genes not specified. 
Table 3 CNVs of unknown clinical relevance (due to unknown parental inheritance)

\begin{tabular}{|c|c|c|c|c|c|c|c|c|}
\hline Case id & $\begin{array}{l}\text { Pregnancy } \\
\text { trimester }\end{array}$ & Clinical features & $\begin{array}{l}\text { Array } \\
\text { platform }\end{array}$ & $\begin{array}{l}\text { Size } \\
(\mathbf{k b})\end{array}$ & Chrom region & $\begin{array}{l}\text { Start-end } \mathrm{Mb} \\
\text { position }(\mathrm{Hg} 19)\end{array}$ & C CNV & $\begin{array}{l}\text { Ref Seq (and/or disease-causing OMIM) } \\
\text { genes involved (UCSC feb 2009) }\end{array}$ \\
\hline 2 & second & $\begin{array}{l}\text { Suspect twin to twin transfusion } \\
\text { syndrome (TTTS), clenched fist both } \\
\text { hands, monozygotic twin }\end{array}$ & $250 \mathrm{k}$ & 663 & $4 q 34.1$ & $173762947-174426181$ & loss & GALNTL6, GALNT7, HMGB2, SAP30, SCRG1 \\
\hline 7 & second & IUGR & $250 \mathrm{k}$ & 447 & $3 q 21.2$ & $125498921-125945498$ & gain & $\begin{array}{l}\text { MIR54811, FAM86JP, ALG1L, ROPN1B, SLC411A3, } \\
\text { ALDH1L1, ALDH1L1-AS1 and AS2 }\end{array}$ \\
\hline 12 & second & MCA & $250 \mathrm{k}$ & 587 & $2 p 12$ & $77036873-77624262$ & loss & LRRTM4 \\
\hline 14 & second & Unknown, recurrent IUFD & $250 \mathrm{k}$ & 1,200 & $6 q 16.1$ & $95641761-96851236$ & gain & MANEA, FUT9, MANEA-AS1 \\
\hline 16 & second & Hygroma colli & $250 \mathrm{k}$ & 1,400 & $1 q 21.1$ & $143570846-144929606$ & loss & $\begin{array}{l}\text { >10 RefSeq genes*, mutation analysis for } \\
\text { Noonan genes: NRAS, SHOC2, GBL, RAF1, SOS1, } \\
\text { KRAS, PTPN11 negative }\end{array}$ \\
\hline 21 & third & Hydrocephaly & CytoScan ${ }^{\circledast} \mathrm{HD}$ & 383 & $16 p 13.3$ & $3945203-4328143$ & loss & $\begin{array}{l}\text { ADCY9, SRL, LOC100507501,TFAP4 (proximal to } \\
\text { OMIM gene CREBBP) }\end{array}$ \\
\hline 30 & second & $\begin{array}{l}\text { Potter's sequence, renal agenesis, facial } \\
\text { dysmorfisms, single palmar crease }\end{array}$ & $250 \mathrm{k}$ & 1,005 & $1 \mathrm{p} 32.3$ & $53484565-54489583$ & gain & $\begin{array}{l}>10 \text { RefSeq genes* and } 3 \text { disease-causing OMIM } \\
\text { genes: SCP2, CPT2, LRP8 }\end{array}$ \\
\hline 34 & unknown & unknown & CytoScan ${ }^{\circledast} \mathrm{HD}$ & 830 & $3 p 24.1$ & $26641410-27471832$ & gain & LRRC3B, NEK10, SLC4A7 \\
\hline 39 & second & None & CytoScan ${ }^{\circledast} \mathrm{HD}$ & 828 & Xq28 & 148839499-149667835 & gain & $\begin{array}{l}\text { MAGEA9B, MAGEA9, MAGEA8-AS1, MAGEA8, CXorf40B, } \\
\text { LINCO0894, MIR2114 and } 1 \text { disease-causing OMIM gene: } \\
\text { MAMLD1 }\end{array}$ \\
\hline 47 & second & None & CytoScan ${ }^{\circledast} \mathrm{HD}$ & 358 & $18 q 21.2$ & 52900743-53258705 & gain & $\begin{array}{l}\text { MIR4529 and disease-causing OMIM gene TCF4. Duplication } \\
\text { TCF4 confirmed by MLPA. }\end{array}$ \\
\hline 50 & third & None & CytoScan ${ }^{\circledast} \mathrm{HD}$ & 545 & 8p21.3p22 & 18825888-19370744 & loss & FSD3, LOC100128993, SH2D4A, CSGALNACT1 \\
\hline 20 & third & None & CytoScan ${ }^{\circledast} \mathrm{HD}$ & 490 & $3 q 29$ & $196592132-197081797$ & gain & $\begin{array}{l}\text { SENP5, NCBP2, NCBP2-AS2, PIG2, MFI2, MFI2-AS1, DLG1, } \\
\text { DLG1-AS1, MIR4797 }\end{array}$ \\
\hline 55 & second & None & CytoScan ${ }^{\circledast} \mathrm{HD}$ & 611 & $16 p 11.2$ & 29567296-30177917 & loss & $\begin{array}{l}>10 \text { RefSeq genes }{ }^{*} \text { and } 3 \text { disease-causing OMIM genes: } \\
\text { KIF22, PRRT2, ALDOA }\end{array}$ \\
\hline 56 & second & Unknown & CytoScan ${ }^{\circledast} \mathrm{HD}$ & 767 & $22 q 11.21$ & 21033398-21800798 & loss & $\begin{array}{l}>10 \text { RefSeq genes* and } 2 \text { disease-causing OMIM genes: } \\
\text { HCF2, SNPA29 }\end{array}$ \\
\hline 59 & third & None & CytoScan HD & 266 & 8p23.3 & 158049-423802 & loss & RPL23AP53, ZNT596, FAM87A, FBX025 \\
\hline
\end{tabular}


In fifteen (8.9\%) samples CNVs (12/15 with sizes $<1 \mathrm{Mb}$, $3 / 15$ with sizes between 1-1.4 Mb) were detected of unknown inheritance (see Table 3). Although parental samples were requested for carrier testing, these have not been received so far.

In nine (5.4\%) samples a parentally inherited $\mathrm{CNV}$ was detected (Table 4): these were all gains ranging with sizes $<1 \mathrm{Mb}$ in $8 / 9$ cases and $1.2 \mathrm{Mb}$ in $1 / 9$ cases (6 out of 8 being maternally inherited).

An overview of all array results is shown in Figure 3.

\section{Regions of Homozygozity (ROH)}

In 25 samples, one or more autosomal $\mathrm{ROHs}$ were detected with a size $\geq 5 \mathrm{Mb}$. From 11 of these samples fetal clinical features were known. By using the online SNP array evaluation tool [24], all genes with recessive inheritance were enumerated to map with the clinical features. In one of these samples (case id. 336), a homozygous mutation in a recessive disease gene was detected. Case id. 336 is a cord biopsy sample from a fetus, from consanguineous parents, that died at 14 weeks of gestation. Postpartum clinical features mentioned on the request form were meningo-encephalocele, a single umbilical artery and suspect for Meckel-Grüber syndrome. Meckel-Grüber syndrome is an autosomal recessive, early embryonic multisystemic disorder (MKS: OMIM 249000). So far, nine different loci have been mapped, including the CEP290 gene. DNA isolated from a cord biopsy showed a normal male profile with QF-PCR and array. However, 12.5\% homozygosity of the autosomal genome was detected, including a pericentromeric segment of $\sim 80 \mathrm{Mb}$ on chromosome 12 encompassing $>50$ genes, among which the CEP290 gene (Figure 4). Subsequent mutation analysis of this gene led to the identification of a pathogenic homozygous missense mutation c.3418G > T. Both parents appeared to be heterozygous carrier of this mutation.

\section{Discussion and conclusions}

In the present study, we evaluated different genetic tests (QF-PCR, karyotyping and array analysis) in the examination of IUFD samples. Our results show that a common aneuploidy was detected in $12 \%$ of the samples which is comparable to a previous report of Korteweg et al. [2] who showed 13\% chromosomal abnormalities in a heterogeneous cohort of fetal deaths. The percentage of aneuploidies was highest (47\%) in first trimester pregnancies. This is in line with the reported incidence of $30-60 \%$ of chromosomal anomalies causing early fetal demise [24-28]. Although cost aspects were not evaluated in our study, aneuploidy detection is cheaper by QF-PCR than by array and therefore QF-PCR analysis is the preferred first tier technique before array analysis to exclude the most common aneuploidies, in particular in case of a first and second trimester IUFD.

The highest incidence of test failures occurred in amniotic fluid samples because of sample contamination. In 2011, we therefore changed our strategy and asked gynecologists to send a fetal biopsy in cases of IUFD instead of amniotic fluid. The quantity of DNA obtained from fetal tissue is usually sufficient, it is clean and therefore suitable for testing by both QF-PCR and array analysis and additional sequencing of single genes in case of a suspected monogenic disorder.

In our cohort with a normal QF-PCR result, a clinically relevant $\mathrm{CNV}$ was detected by array in $4.2 \%$ of the samples, varying in size from 1.1 to $48.0 \mathrm{Mb}$ and all concerning fetuses with malformations. This is lower than reported in literature. However, in these papers, the genome-wide prevalence of CNVs was examined in truly unexplained stillbirth, resulting in an overall detection ranging from $8-13 \%[11,29]$. Retrospective studies in fetuses with multiple malformations also obtained a detection rate of causative imbalances from 8 to $15 \%$, including

Table 4 Inherited CNVs ( $\mathbf{N}=9$ )

\begin{tabular}{|c|c|c|c|c|c|c|c|c|}
\hline Case id & $\begin{array}{l}\text { Pregnancy } \\
\text { trimester }\end{array}$ & Clinical features & Array platform & $\begin{array}{l}\text { Size } \\
(\mathbf{k b})\end{array}$ & $\begin{array}{l}\text { Chromosomal } \\
\text { region }\end{array}$ & Inheritance & $\begin{array}{l}\text { Start-end Mb } \\
\text { position (Hg19) }\end{array}$ & CNV \\
\hline 242 & second & $\begin{array}{l}\text { Recurrent miscarriages, } \\
\text { micrognatia }\end{array}$ & $250 \mathrm{k}$ & 559 & $22 q 12.3$ & maternal & $31829608-32388222$ & gain \\
\hline 257 & second & Unknown & $250 k$ & 400 & $1 \mathrm{p} 31.1$ & maternal & $71586877-71986553$ & gain \\
\hline 272 & second & $\begin{array}{l}\text { Hydrops fetalis, low-set ears, } \\
\text { Pierre Robin Sequence (PRS) }\end{array}$ & CytoScan ${ }^{\oplus} \mathrm{HD}$ & 303 & Xq24 & maternal & 118733984-119037053 & gain \\
\hline 280 & second & Unknown & CytoScan ${ }^{\circledast} \mathrm{HD}$ & 251 & $6 \mathrm{q} 27$ & paternal & $169570833-169822659$ & gain \\
\hline 281 & second & $\begin{array}{l}\text { Mild facial dysmorfic features, } \\
\text { hypertelorism, long philtrum }\end{array}$ & CytoScan ${ }^{\circledast} \mathrm{HD}$ & 1,200 & $1 q 43$ & maternal & 236830156-238009186 & gain \\
\hline 289 & second & $\begin{array}{l}\text { Agenesis of the corpus callosum } \\
\text { (ACC), hydrops fetalis, ascites, } \\
\text { mild ventriculomegaly }\end{array}$ & CytoScan ${ }^{\circledast} \mathrm{HD}$ & 260 & $9 q 21.11$ & maternal & $71570080-71842392$ & gain \\
\hline 316 & second & Unknown & CytoScan ${ }^{\circledast} \mathrm{HD}$ & 367 & $16 p 13.3$ & maternal & 5393095-5760407 & gain \\
\hline 359 & second & None (recurrent miscarriages) & CytoScan ${ }^{\circledast} \mathrm{HD}$ & 990 & $7 q 11.21$ & paternal & 65329349-66417018 & gain \\
\hline 65 & second & Unknown (macerated fetus) & CytoScan ${ }^{\circledast} \mathrm{HD}$ & 294 & Xp22.31 & paternal & 8439472-8733564 & gain \\
\hline
\end{tabular}




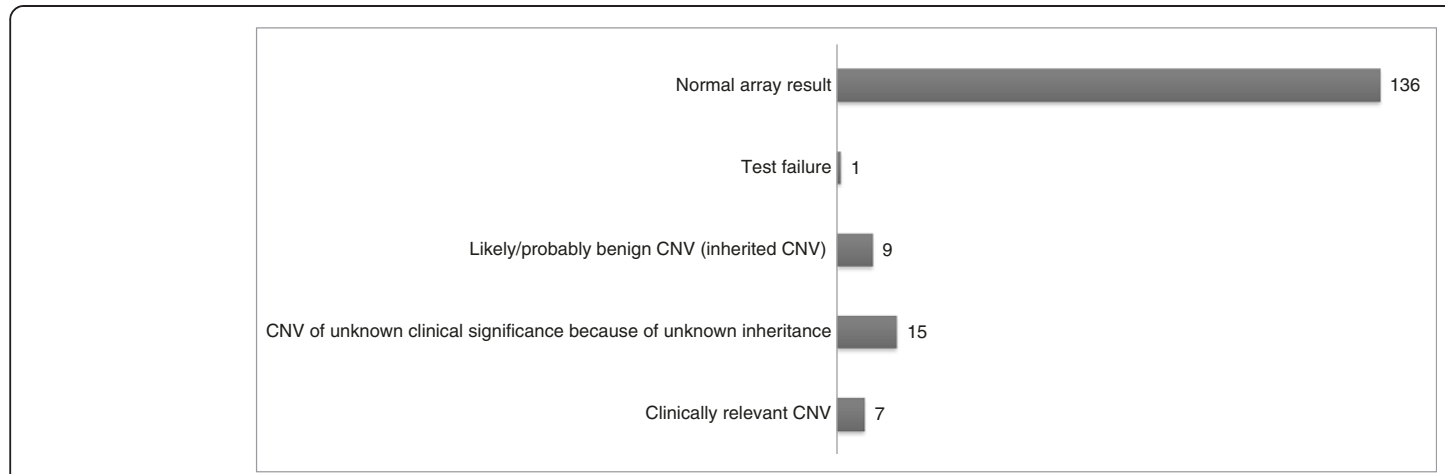

Figure 3 Overview of array results: type and number of CNVs detected in 168 samples with IUFD.

common aneuploidies, by using array [7,30-32]. Our cohort tested by array, however, consisted of a heterogeneous group of fetal deaths, excluding a common aneuploidy which could clarify our lower detection rate.

Overall, in $8.9 \%$ of the samples a CNV was detected with unknown inheritance, most of which (12/15) smaller than $1 \mathrm{Mb}$ in size. In contrast to our routine prenatal diagnostic array workflow, in which it is highly recommended to include parental samples simultaneously, in IUFD genetic analysis, testing of parental samples is requested in our written report only after a likely pathogenic $\mathrm{CNV}$ has been detected. To reduce the

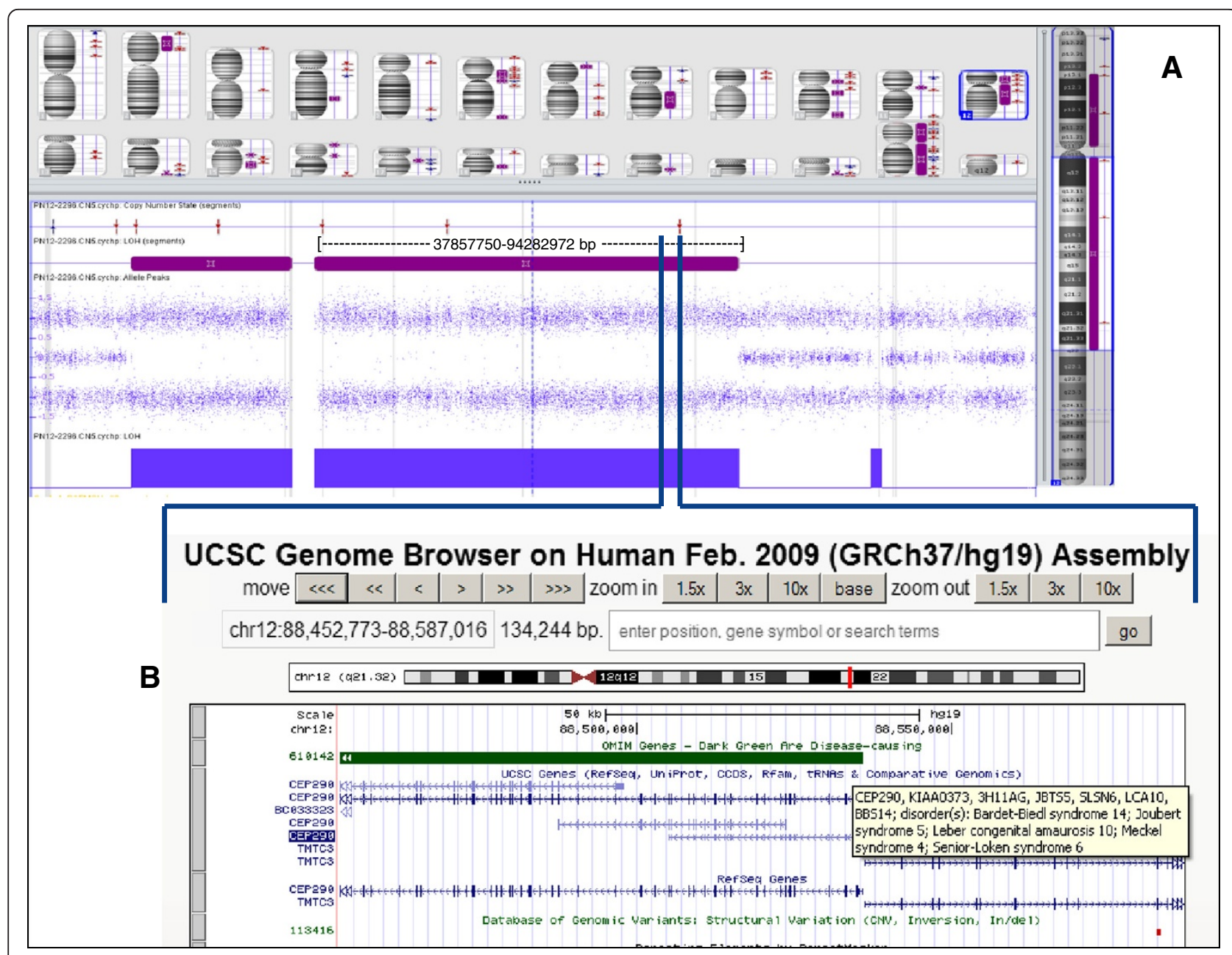

Figure 4 A region of homozygosity in chromosome 12, including the CEP290 gene. 
number of results with CNVs of unknown inheritance and therefore unknown clinical relevance, the maximum effort possible should be undertaken to obtain parental blood for testing. Subsequently, finding the cause of the IUFD is helpful to better understand the cause of death, to more accurately determine the recurrence risks, and to enable possible future testing in some cases.

In eight (4.8\%) samples a CNV inherited from a healthy parent was detected. Although not all inherited $\mathrm{CNVs}$ can always be classified as benign and without clinical relevance with certainty, they are, dependent on the size and the type of CNV, less likely to directly lead to a clinical phenotype: small CNVs $(<0.1 \mathrm{Mb})$ and gains are less likely to be pathogenic than large CNVs (>1 Mb) and losses, respectively [33,34]. All inherited CNVs in this study were gains ranging in size from $\sim 250-1,200 \mathrm{~kb}$, mostly maternally inherited and most likely benign.

The utility of high density SNP arrays is not only useful to rule out potential sample mismatch or falsepaternity, but is also used in our laboratory for the examination of regions of homozygosity $(\mathrm{ROH})[16,35]$ and to identify excessive homozygosity, and with specific clinical information the possibility for follow-up diagnostic testing. A nice example in our cohort for demonstrating the power of homozygosity mapping was case id. 336, suspect for Meckel-Grüber syndrome. A homozygous mutation was found in CEP290, one of the genes within a large, $80 \mathrm{Mb} \mathrm{ROH}$. Both parents appeared to be heterozygous carriers of this mutation. The Genomic Oligoarray and SNP array evaluation tool enables to evaluate homozygous stretches for autosomal recessive genes in combination with a clinical phenotype making it possible to strategize more focused diagnostic testing [24]. Therefore, we emphasize the need to have detailed phenotypic information to make optimal use of the genotype data from SNP arrays in finding candidate recessive disease genes that may be related to the fetal phenotype.

In concordance with the results of a study of 532 stillbirth samples [36], we conclude that array analysis is more likely to provide an accurate genetic diagnosis than by traditional karyotyping, primarily because of its success with nonviable tissue, making array particularly valuable in the analysis of stillbirths with congenital anomalies. An increased detection rate of chromosomal abnormalities is found when array analysis is used to examine products of conception [37], however, further work is required before the absolute detection rate can be answered.

Nowadays, next-generation sequencing (NGS) is increasingly being used in genetic diagnostics for studying congenital malformations, intellectual disability, and other heterogeneous disorders. Although mutations in genes are known to cause fetal death [38], a systematic genome-wide study has not been performed yet, leaving a large proportion of fetal demise unexplained. It is already demonstrated that NGS not only enables the detection of Single Nucleotide Variation but CNVs as well [39], thus very soon replacing genome wide array analysis in diagnostics. Implementation of NGS for $\mathrm{CNV}$ detection and genome/exome wide sequencing in the work-up of IUFD will not only lead to a further improvement of the detection rate, but also to a better fundamental insight in fetal and placental development, and possible maternal interactions.

\section{Competing interest}

The authors declare that they have no competing interests.

\section{Authors' contributions}

All authors contributed to the interpretation of the diagnostic test findings and participated in the diagnostic service of the Department of Human Genetics. AK compiled the data and wrote most of the manuscript with active cooperation by all authors. All authors read and approved the final version of the manuscript.

\section{Acknowledgements}

The authors thank the Array-, Fertility \& Pregnancy and Bioinformatics groups of the Department of Human Genetics, Radboud university medical center, for their technical support.

Received: 21 October 2013 Accepted: 17 December 2013

Published: 16 January 2014

\section{References}

1. Silver RM: Fetal death. Obstet Gynecol 2007, 110(1):191.

2. Korteweg FJ, Bouman K, Erwich JJ, Timmer A, Veeger NJ, Ravisé JM, Nijman TH, Holm JP: Cytogenetic analysis after evaluation of 750 fetal deaths: proposal for diagnostic workup. Obstet Gynecol 2008, 111(4):865-874.

3. Warburton D, Kline J, Stein Z, Strobino B: Cytogenetic abnormalities in spontaneous abortions of recognized conceptions. In Perinatal Genetics: Diagnosis and Treatment. Edited by Porter $\mathrm{HH}$, Hatcher NH, Willey AM. Orlando, Fla.: Academic Press; 1986:23-40.

4. Naeye RL: Functionally important disorders of the placenta, umbilical cord, and fetal membranes. Hum Pathol 1987, 18:680-691.

5. Heifetz SA: The umbilical cord: obstetrically important lesions. Clin Obstet Gynecol 1996, 39:571-587.

6. Klimann HJ: Umbilical cord. In Encyclopedia of Reproduction, vol 4. Edited by Knobil E, Neill JD. San Diego: Academic; 1999:915-923.

7. Schaeffer AJ, Chung J, Heretis K, Wong A, Ledbetter DH, Lese Martin C Comparative genomic hybridization-array analysis enhances the detection of aneuploidies and submicroscopic imbalances in spontaneous miscarriages. Am J Hum Genet 2004, 74(6):1168-1174.

8. Jurkovic D, Overton C, Bender-Atik R: Diagnosis and management of first trimester miscarriage. BMJ 2013, 346:f3676.

9. Simpson JL: Obstetrics. In Normal and Problem Pregnancies. 3rd edition. Edited by Gabbe SG, Niebyl JR, Simpson JL. New York, N.Y: Churchill Livingstone; 1996:717-742.

10. Menten B, Swerts K, Delle Chiaie B, Janssens S, Buysse K, Philippé J, Speleman F: Array comparative genomic hybridization and flow cytometry analysis of spontaneous abortions and mors in utero samples. BMC Med Genet 2009, 14:10-89.

11. Reddy UM, Page GP, Saade GR: The role of DNA microarrays in the evaluation of fetal death. Prenat Diagn 2012, 32(4):371-375.

12. de Vries BB, Pfundt R, Leisink M, Koolen DA, Vissers LE, Janssen IM, Reijmersdal S, Nillesen WM, Huys EH, Leeuw N, Smeets D, Sistermans EA Feuth T, van Ravenswaaij-Arts CM, van Kessel AG, Schoenmakers EF, Brunner HG, Veltman JA: Diagnostic genome profiling in mental retardation. Am J Hum Genet 2005, 77(4):606-616.

13. Faas BH, van der Burgt I, Kooper AJ, Pfundt R, Hehir-Kwa JY, Smits AP, de Leeuw N: Identification of clinically significant, submicroscopic 
chromosome alterations and UPD in fetuses with ultrasound anomalies using genome-wide 250 k SNP array analysis. J Med Genet 2010, 47(9):586-594

14. Nannya Y, Sanada M, Nakazaki K, Hosoya N, Wang L, Hangaishi A, Kurokawa M, Chiba S, Bailey DK, Kennedy GC, Ogawa S: A robust algorithm for copy number detection using high-density oligonucleotide single nucleotide polymorphism genotyping arrays. Cancer Res 2005, 15(65(14)):6071-6079.

15. Vissers $L E$, de Vries $B B$, Veltman JA: Genomic microarrays in mental retardation: from copy number variation to gene, from research to diagnosis. J Med Genet 2010, 47(5):289-297.

16. de Leeuw N, Hehir-Kwa JY, Simons A, GeurtsvanKessel A, Smeets DF, Faas BH, Pfundt R: SNP array analysis in constitutional and cancer genome diagnostics-copy number variants, genotyping and quality control. Cytogenet Genome Res 2011, 135(3-4)):212.

17. Lichtenbelt KD, Knoers NV, Schuring-Blom GH: From karyotyping to arrayCGH in prenatal diagnosis. Cytogenet Genome Res 2011, 135(3-4):241-250

18. Wapner RJ, Martin CL, Levy B, Ballif BC, Eng CM, Zachary JM, Savage M, Platt LD, Saltzman D, Grobman WA, Klugman S, Scholl T, Simpson JL, McCall K, Aggarwal VS, Bunke B, Nahum O, Patel A, Lamb AN, Thom EA, Beaudet AL, Ledbetter DH, Shaffer LG, Jackson L: Chromosomal microarray versus karyotyping for prenatal diagnosis. N Engl J Med 2012, 367(23):2175-2184.

19. Rajcan-Separovic E: Chromosome microarrays in human reproduction. Hum Reprod Update 2012, 18(5):555-567.

20. Faas BH, Feenstra I, Eggink AJ, Kooper AJ, Pfundt R, van Vugt JM, de Leeuw N: Non-targeted whole genome $250 \mathrm{~K}$ SNP array analysis as replacement for karyotyping in fetuses with structural ultrasound anomalies: evaluation of a one-year experience. Prenat Diagn 2012, 32(4):362-370.

21. Robberecht C, Schuddinck V, Fryns JP, Vermeesch JR: Diagnosis of miscarriages by molecular karyotyping: benefits and pitfalls. Genet Med 2009, 11(9):646-654

22. Gao J, Liu C, Yao F, Hao N, Zhou J, Zhou Q, Zhang L, Liu X, Bian X, Liu J: Array-based comparative genomic hybridization is more informative than conventional karyotyping and fluorescence in situ hybridization in the analysis of first-trimester spontaneous abortion. Mol Cytogenet 2012, 16(5(1)):33.

23. Church DM, Lappalainen I, Sneddon TP, Hinton J, Maguire M, Lopez J, Garner J, Paschall J, DiCuccio M, Yaschenko E, Scherer SW, Feuk L, Flicek P: Public data archives for genomic structural variation. Nat Genet 2010, 42:813-814.

24. Wierenga KJ, Jiang Z, Yang AC, Mulvihill JJ, Tsinoremas NF: A clinical evaluation tool for SNP arrays, especially for autosomal recessive conditions in offspring of consanguineous parents. Genet Med 2013, 15(5):354-360.

25. Hassold T, Chen N, Funkhouser J, Jooss T, Manuel B, Matsuura J, Matsuyama A, Wilson C, Yamane JA, Jacobs PA: A cytogenetic study of 1000 spontaneous abortions. Annals of Hum Genet 1980, 44:151-178.

26. Kajii T, Ferrier A, Niikawa N, Takahara H, Ohama K, Avirachan S: Anatomic and chromosomal anomalies in 639 spontaneous abortions. Hum Genet 1980, 55:87-93.

27. Byrne J, Warburton D, Kline J, Blanc W, Stein Z: Morphology of early fetal deaths and their chromosomal characteristics. Teratology 1985 , 32:297-315

28. Ljunger $\mathrm{E}$, Cnattingius $\mathrm{S}$, Lundin $\mathrm{C}$, Annerén G: Chromosomal anomalies in first-trimester miscarriages. Acta Obstet Gynecol Scand 2005, 84(11):1103-1107.

29. Raca G, Artzer A, Thorson L, Huber S, Modaff P, Laffin J, Pauli RM: Arraybased comparative genomic hybridization $(\mathrm{aCGH})$ in the genetic evaluation of stillbirth. Am J Med Genet A 2009, 149A(11):2437-2443.

30. Le Caignec C, Boceno M, Saugier-Veber P, Jacquemont S, Joubert M, David A, Frebourg T, Rival JM: Detection of genomic imbalances by array based comparative genomic hybridisation in fetuses with multiple malformations. J Med Genet 2005, 42(2):121-128.

31. Vialard F, Molina Gomes D, Leroy B, Quarello E, Escalona A, Le Sciellour C, Serazin $V$, Roume J, Ville $Y$, de Mazancourt $P$, Selva J: Array comparative genomic hybridization in prenatal diagnosis: another experience. Fetal Diagn Ther 2009, 25(2):277-284

32. Warren JE, Turok DK, Maxwell TM, Brothman AR, Silver RM: Array comparative genomic hybridization for genetic evaluation of fetal loss between 10 and 20 weeks of gestation. Obstet Gynecol 2009, 114(5):1093-1102
33. Lee $C$, lafrate A, Brothman A: Copy number variants and clinical cytogenetic diagnosis of constitutional disorders. Nat Genet 2007, 39:S48-S54

34. Vermeesch JR, Fiegler $H$, de Leeuw N, Szuhai K, Schoumans J, Ciccone R, Speleman F, Rauch A, Clayton-Smith J, Van Ravenswaaij C, Sanlaville D, Patsalis PC, Firth H, Devriendt K, Zuffardi O: Guidelines for molecular karyotyping in constitutional genetic diagnosis. Eur J Hum Genet 2007 15:1105-1114.

35. Kearney HM, Kearney JB, Conlin LK: Diagnostic implications of excessive homozygosity detected by SNP-based microarrays: consanguinity, uniparental disomy, and recessive single-gene mutations. Clin Lab Med 2011, 31(4):595-613.

36. Reddy UM, Page GP, Saade GR, Silver RM, Thorsten VR, Parker CB, Pinar $H$ Willinger M, Stoll BJ, Heim-Hall J, Varner MW, Goldenberg RL, Bukowski R, Wapner RJ, Drews-Botsch CD, O'Brien BM, Dudley DJ, Levy B, NICHD Stillbirth Collaborative Research Network: Karyotype versus microarray testing for genetic abnormalities after stillbirth. N Engl J Med 2012, 367(23):2185-2193.

37. Dhillon R, Hillman S, Morris R, McMullan D, Williams D, Coomarasamy A, Kilby M: Additional information from chromosomal microarray analysis (CMA) over conventional karyotyping when diagnosing chromosomal abnormalities in miscarriage: a systematic review and meta-analysis. BJOG 2013. doi:10.1111/1471-0528.12382.

38. Crotti L, Tester DJ, White WM, Bartos DC, Insolia R, Besana A, Kunic JD, Wil ML, Velasco EJ, Bair JJ, Ghidoni A, Cetin I, Van Dyke DL, Wick MJ, Brost B, Delisle BP, Facchinetti F, George AL, Schwartz PJ, Ackerman MJ: Long QT syndrome-associated mutations in intrauterine fetal death. JAMA 2013, 309(14):1473-1482

39. de Ligt J, Boone PM, Pfundt R, Vissers LE, Richmond T, Geoghegan J, O'Moore K, de Leeuw N, Shaw C, Brunner HG, Lupski JR, Veltman JA, Hehir-Kwa JY: Detection of clinically relevant copy number variants with whole-exome sequencing. Hum Mutat 2013, 34(10):1439-1448.

doi:10.1186/1755-8166-7-6

Cite this article as: Kooper et al:: Best diagnostic approach for the genetic evaluation of fetuses after intrauterine death in first, second or third trimester: QF-PCR, karyotyping and/or genome wide SNP array analysis. Molecular Cytogenetics 2014 7:6

\section{Submit your next manuscript to BioMed Central and take full advantage of:}

- Convenient online submission

- Thorough peer review

- No space constraints or color figure charges

- Immediate publication on acceptance

- Inclusion in PubMed, CAS, Scopus and Google Scholar

- Research which is freely available for redistribution 